\title{
Detection of infectious salmon anaemia virus by real-time nucleic acid sequence based amplification
}

\author{
William G. Starkey ${ }^{1, *}$, David A. Smail ${ }^{2}$, Hogne Bleie ${ }^{3}$, K. Fiona Muir ${ }^{1}$, \\ Jacqueline H. Ireland ${ }^{1}$, Randolph H. Richards ${ }^{1}$ \\ ${ }^{1}$ Department of Virology, Institute of Aquaculture, University of Stirling, Stirling FK9 4LA, UK \\ ${ }^{2}$ F.R.S. Marine Laboratory, PO Box 101, Aberdeen AB11 9DB, UK \\ ${ }^{3}$ National Veterinary Institute, PO Box 1263, Sentrum, 5811 Bergen, Norway
}

\begin{abstract}
We have developed a real-time nucleic acid sequence based amplification (NASBA) procedure for detection of infectious salmon anaemia virus (ISAV). Primers were designed to target a 124 nucleotide region of ISAV genome segment 8. Amplification products were detected in real-time with a molecular beacon (carboxyfluorescin [FAM]-labelled and methyl-red quenched) that recognised an internal region of the target amplicon. Amplification and detection were performed at $41^{\circ} \mathrm{C}$ for $90 \mathrm{~min}$ in a Corbett Research Rotorgene. The real-time NASBA assay was compared to a conventional RT-PCR for ISAV detection. From a panel of 45 clinical samples, both assays detected ISAV in the same 19 samples. Based on the detection of a synthetic RNA target, the real-time NASBA procedure was approximately $100 \times$ more sensitive than conventional RT-PCR. These results suggest that real-time NASBA may represent a useful diagnostic procedure for ISAV.
\end{abstract}

KEY WORDS: Infectious salmon anaemia virus - Orthomyxovirus · NASBA · Diagnostics · Fish · Nucleic acid amplification

\section{INTRODUCTION}

Infectious salmon anaemia (ISA) is a disease of Atlantic salmon Salmo salar L. that has caused extensive financial losses in the aquaculture industry. The clinical signs of ISA include pale gills, ascites, hepatic and splenic enlargement, petechiae within visceral fat, and severe anaemia associated with high mortality (Hovland et al. 1994). ISA may also be associated with other disease manifestations including haemorrhagic kidney syndrome (HKS), and haemorrhagic abnormalities in the gill filaments and the gastrointestinal wall (Dale et al. 2005).

The aetiological agent of ISA, infectious salmon anaemia virus (ISAV), is a member of the family Orthomyxoviridae recently proposed to represent the type species of the genus Isavirus (Anonymous 2002). ISA was first reported in Norway in 1984 (Thorud \&
Djupvik 1988) and has since occurred in Scotland, Ireland, Canada, USA, and the Faroe Islands. ISAV has also been detected in Coho salmon Oncorhynchus kisutch in Chile (Kibenge et al. 2001). ISAV can infect several other species of fish including freshwater brown trout Salmo trutta (Nylund et al. 1995), sea trout Salmo trutta (Nylund \& Jakobsen 1995), rainbow trout Oncorhynchus mykiss (Nylund et al. 1997), and Atlantic herring Clupea harengus (Nylund et al. 2002).

ISAV is an enveloped virus 45 to $140 \mathrm{~nm}$ in diameter (Dannevig et al. 1995). The ISAV genome is comprised of 8 segments of single stranded negative-polarity RNA ranging from 1 to $2.3 \mathrm{~kb}$ (Mjaaland et al. 1997). The nucleotide sequence of all ISAV genome segments has been determined (Clouthier et al. 2002), and significant sequence variation shown to occur between different ISAV isolates (Krossoy et al. 2001). 
Sensitive and specific diagnostic procedures are essential for the effective control of ISA. Methods currently used for the detection of ISAV include virus isolation in SHK-1, ASK, or CHSE-214 cells (Cipriano \& Miller 2003), in situ hybridization (Gregory 2002), indirect fluorescent antibody testing (Falk \& Dannevig 1995), and RT-PCR (Mjaaland et al. 1997, Rimstad et al. 1999, Devold et al. 2000). A real-time RT-PCR method for the diagnosis of ISAV utilising SyBr Green I detection of amplification products has been described by Munir \& Kibenge (2004).

Nucleic acid sequence based amplification (NASBA) is an isothermal nucleic acid amplification procedure based on the activity of 3 enzymes; reverse transcriptase, RNase $\mathrm{H}$, and T7 RNA polymerase (Compton 1991). Real-time detection in NASBA can be performed using molecular beacon probes (Leone et al. 1998). NASBA detection methods have been described for several viruses including human immunodeficiency virus type 1 (de Baar et al. 1999), cytomegalovirus (Witt et al. 2000), West-Nile and St Louis encephalitis viruses (Lanciotti \& Kerst 2001), enterovirus (Heim \& Schumann 2002), parainfluenza virus (Hibbitts et al. 2003), influenza A virus (Moore et al. 2004), betanodavirus (Starkey et al. 2004) and SARS-associated coronavirus (Keightley et al. 2005).

In the present study we report on the development of a real-time NASBA procedure for detection of ISAV. The real-time NASBA assay was compared to a conventional RT-PCR assay for ISAV using previously described primers (Mjaaland et al. 1997).

\section{MATERIALS AND METHODS}

Clinical samples. A panel of 45 clinical samples (Atlantic salmon kidney) obtained from outbreaks of ISA in Scotland, the Faroe Islands and Norway was used in this study (see Table 1). Samples 1 to 20 were archival, and following collection were stored at $-70^{\circ} \mathrm{C}$. Samples 21 to 45 were obtained from Atlantic salmon during an outbreak of ISA, and were stored in RNAlater (Ambion) at $-20^{\circ} \mathrm{C}$.

RNA isolation. Isolation of RNA from tissue samples for use in both RT-PCR and NASBA was performed using the Nucleospin procedure (Machery Nagel) according to the manufacturer's recommendations.

RT-PCR. Conventional RT-PCR was performed using the Ready-to-Go kit (Pharmacia). The reaction buffer contained $10 \mathrm{mM}$ Tris- $\mathrm{HCl}(\mathrm{pH} 9.0), 60 \mathrm{mM} \mathrm{KCl}$, $1.5 \mathrm{mM} \mathrm{MgCl} 2,200 \mu \mathrm{M}$ of each dNTP, and porcine ribonuclease inhibitor. Oligonucleotide primers (GGCTATCTACCATGAACGAATC and GCCAAGTGTAA GTAGCACTCC) amplified a 155 nucleotide region of ISAV genome segment 8 (Mjaaland et al. 1997).
Reverse transcription and thermal cycling were performed at $42^{\circ} \mathrm{C}$ for $30 \mathrm{~min}, 95^{\circ} \mathrm{C}$ for $5 \mathrm{~min}$, followed by 32 cycles of $95^{\circ} \mathrm{C}$ for $1 \mathrm{~min}, 55^{\circ} \mathrm{C}$ for $1 \mathrm{~min}$ and $72^{\circ} \mathrm{C}$ for $1 \mathrm{~min}$. Amplification products were analysed in 1\% agarose gels, stained with ethidium bromide and visualised under UV illumination.

Real-time NASBA. Primers for use in NASBA were synthesised by MWG Biotech (Milton Keynes, UK), and were designed to amplify a 124 nucleotide region of ISAV genome segment 8. A CLUSTAL-X alignment of 17 ISAV segment 8 sequences deposited in GenBank was used to aid the design of primers: AF262386, AF262380, AF262385, AJ012285.1, Y10404.1, AF262382, AF262381, AF262384, AF262387, AF262383, AF262388, AJ242016, RPC/NB-877, AF312316, AF312315, AF312317, and RPC/NB-282-2. Primers were designed to target conserved regions of genome segment 8 . The upstream primer contained a 5 ' modification corresponding to a T7 RNA polymerase promoter, followed by a 6 base pair purine-rich linker segment to facilitate efficient amplification. The nucleotide sequence of the upstream primer was AATTCTAATACGACTCACTATAGGGAGAAGGACGCGGATGGTGGAGAGGAA and the downstream primer was GCATACATCTGCATCCT GC. The T7 polymerase promoter sequence in the upstream primer is underlined, and the purine-rich linker sequence is depicted in bold type.

The molecular beacon probe was synthesised by Oswel Research Products (Southampton, UK). The beacon was designed to target a region of the amplification product 20 nucleotides in length, and was synthesised with a 5'-FAM modification as a fluorophore, and a $3^{\prime}$-methyl-red modification as quencher. The predicted secondary structure of the probe was analysed using the Mfold 3.1 algorithm (Zuker 2003; available at: www.bioinfo.rpi.edu/applications/mfold/ old/dna/form1.cgi.

The nucleotide sequence of the molecular beacon was 5'-FAM-CGATCGCATACCATACACCATTGCCC CGATCG-methyl red-3'. The complementary 5' and 3' arm sequences are underlined, and the secondary structure is shown in Fig. 1.

NASBA was performed using the NucliSens Basic Kit amplification reagents (Biomerieux) according to the manufacturer's instructions. Briefly, $5 \mu \mathrm{l}$ of RNA was mixed with $10 \mu \mathrm{l}$ amplification mix (80 mM Tris$\mathrm{HCl} \mathrm{pH}$ 8.5, $24 \mathrm{mM} \mathrm{MgCl}, 140 \mathrm{mM} \mathrm{KCl}, 10 \mathrm{mM}$ dithiothreitol, $2.0 \mathrm{mM}$ each of dATP, dCTP, dGTP, dTTP, $4.0 \mathrm{mM}$ each of ATP, CTP, GTP, UTP, $0.4 \mu \mathrm{M}$ upstream and downstream primers, $0.25 \mu \mathrm{M}$ molecular beacon probe, in $30 \%$ dimethyl sulfoxide). The mixture was heated to $65^{\circ} \mathrm{C}$ for $5 \mathrm{~min}$ then cooled to $41^{\circ} \mathrm{C}$ for 5 min prior to addition of $5 \mu \mathrm{l}$ enzyme mix (avian myeloblastosis virus reverse transcriptase $1.3 \mathrm{U} \mathrm{ml}^{-1}$, RNase $\mathrm{H} 0.02 \mathrm{U} \mathrm{ml}^{-1}$, T7 RNA polymerase $6.4 \mathrm{U} \mathrm{ml}^{-1}$ ). 


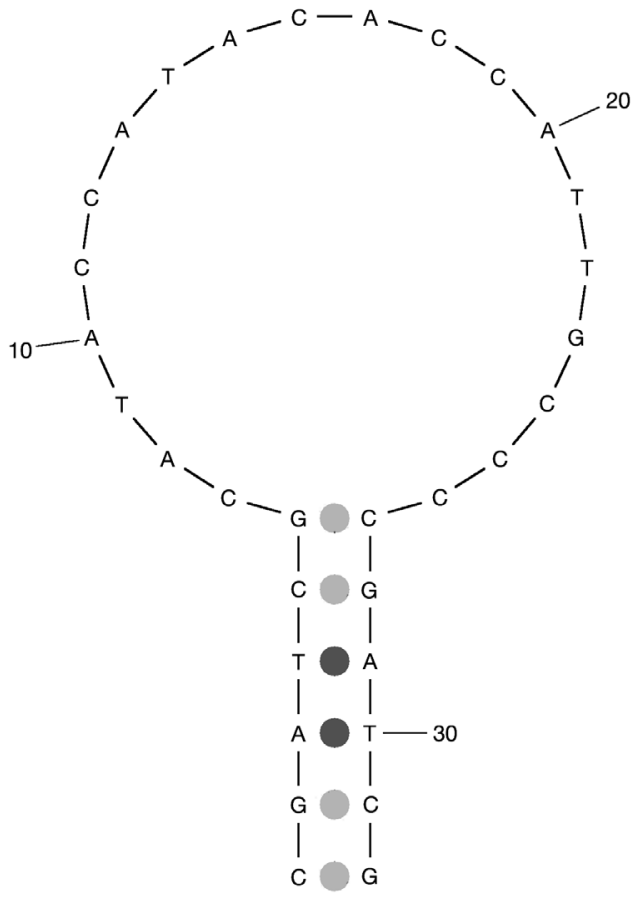

Fig. 1. Molecular beacon used for detection of infectious salmon anaemia virus (ISAV). Nucleotide sequence and predicted secondary structure in the absence of target amplicon analysed with Mfold 3.1 (Zuker 2003). C residue at position 1 was labelled with FAM; G residue at position 32 carried a methyl-red modification as a quencher

NASBA was performed at $41^{\circ} \mathrm{C}$ for $90 \mathrm{~min}$ in a Rotorgene (Corbett Research).

Amplification was monitored in real-time using an excitation wavelength of $470 \mathrm{~nm}$ and fluorescent detection at $510 \mathrm{~nm}$. Fluorescent data were collected at intervals of $60 \mathrm{~s}$. RNA extracted from a Scottish ISAV isolate propagated in SHK-1 cells was used as a positive control. Negative (no template) controls were also included in amplification runs. Test samples were classified as positive or negative using a modification of the method used by Lanciotti \& Kerst (2001). This was based on the time to positivity ( $\mathrm{Tp}$; in minutes) at which sample fluorescence increased above a threshold value, and on the relative increase in sample fluorescence ( $\mathrm{Rn})$. The threshold was positioned above the background fluorescence of no-template control samples such that it intersected the exponential part of amplification reactions. On this basis a threshold of 0.1 was used in all experiments. Samples with $\mathrm{Tp}$ values $<90$ min were considered positive, provided that their Rn value was not less than $25 \%$ of the $\mathrm{Rn}$ value detected for the positive control. Data processing was performed using Rotorgene software version 6 .

Synthetic RNA transcript. A synthetic RNA transcript corresponding to nucleotides 1 to 872 of ISAV genome segment 8 was prepared using an RT-PCR derived template and a commercial kit (MegascriptT3, Ambion) according to the manufacturer's instructions. The ISAV strain used to produce the transcript was isolated from Scotland (Cunningham \& Snow 2000). The nucleotide sequence of segment 8 of this isolate is archived under Genbank accession no. AJ242016. The synthetic transcript was analysed by gel electrophoresis and the RNA molar concentration determined by UV spectrophotometry. RNA concentration was converted to copies per microlitre using Avogadro's number $\left(6.022 \times 10^{23}\right)$.

Statistical analyses. ANOVA was performed using a web based statistics package available at www. physics.csbsju.edu/stats/anova.html

\section{RESULTS}

\section{Real-time NASBA detection of ISAV in clinical samples}

A panel of 45 clinical samples obtained from outbreaks of ISA was studied using the real-time NASBA assay. The results are summarised in Table 1 in comparison to those obtained using conventional RT-PCR. The real-time NASBA assay identified 19 positive and 26 negative samples. These results were in exact agreement with those obtained using RT-PCR.

\section{Detection limit and dynamic range}

The detection limit and dynamic range of the realtime ISAV NASBA assay were determined by testing a decimal dilution series of a synthetic RNA corresponding to an 872 nucleotide fragment of ISAV genome segment 8 (Fig. 2A,B). The assay detection limit was between $10^{2}$ and $10^{1}$ target copies, and the dynamic range was 6 orders of magnitude $\left(R^{2}=0.992\right)$. The detection limit of the conventional RT-PCR assay was between $10^{4}$ and $10^{3}$ copies (data not shown).

The detection limits of the real-time NASBA and RTPCR assays were also investigated using clinical samples. Decimal dilutions of 3 clinical samples were used to determine the detection limit of both assays. The real-time NASBA assay was $100 \times$ more sensitive than conventional RT-PCR (Table 2).

\section{Intra-assay and inter-assay variation}

The intra-assay variation of the ISAV real-time NASBA assay was determined by testing 10 replicates of 3 samples containing different amounts of ISAV (Table 3). Replicates were tested in a single amplification run. The coefficient of variation $(\mathrm{CV})$ of $\mathrm{Tp}$ values varied from 3.61 to $9.77 \%$. 
Table 1. Comparison of real-time nucleic acid sequence based amplification (NASBA) and RT-PCR for detection of ISAV in a panel of 45 clinical samples. $\mathrm{Tp}=$ time (in $\min$ ) to positivity; $\mathrm{Tp}$ values $<90 \mathrm{~min}$ are considered positive results (see 'Materials and methods')

\begin{tabular}{|c|c|c|}
\hline & NASBA (Tp) & RT-PCR \\
\hline \multicolumn{3}{|c|}{ Faroes 2000} \\
\hline 1 & $>90$ & - \\
\hline 2 & $>90$ & - \\
\hline 3 & $>90$ & - \\
\hline 4 & $>90$ & - \\
\hline 5 & 20.94 & + \\
\hline 6 & 19.53 & + \\
\hline 7 & 14.58 & + \\
\hline 8 & 16.94 & + \\
\hline 9 & 14 & + \\
\hline 10 & $>90$ & - \\
\hline \multicolumn{3}{|c|}{ Scotland 1998} \\
\hline 11 & 15.82 & + \\
\hline 12 & 15.47 & + \\
\hline 13 & 20.45 & + \\
\hline 14 & 15.09 & + \\
\hline 15 & 14.61 & + \\
\hline 16 & 15.96 & + \\
\hline 17 & 15.26 & + \\
\hline 18 & 15.42 & + \\
\hline 19 & 16.07 & + \\
\hline 20 & 16.08 & + \\
\hline \multicolumn{3}{|c|}{ Norway 2004} \\
\hline 21 & 33.7 & + \\
\hline 22 & $>90$ & - \\
\hline 23 & $>90$ & - \\
\hline 24 & $>90$ & - \\
\hline 25 & $>90$ & - \\
\hline 26 & $>90$ & - \\
\hline 27 & 45.22 & + \\
\hline 28 & $>90$ & - \\
\hline 29 & $>90$ & - \\
\hline 30 & $>90$ & - \\
\hline 31 & $>90$ & - \\
\hline 32 & 47.56 & + \\
\hline 33 & $>90$ & - \\
\hline 34 & $>90$ & - \\
\hline 35 & $>90$ & - \\
\hline 36 & $>90$ & - \\
\hline 37 & $>90$ & - \\
\hline 38 & 39.47 & + \\
\hline 39 & $>90$ & - \\
\hline 40 & $>90$ & - \\
\hline 41 & $>90$ & - \\
\hline 42 & $>90$ & - \\
\hline 43 & $>90$ & - \\
\hline 44 & $>90$ & - \\
\hline 45 & $>90$ & - \\
\hline
\end{tabular}

Inter-assay variation was determined by testing 10 replicates of a single sample in 4 separate amplification runs (Table 3 ). The mean Tp value obtained in the 4 experiments varied from 25.3 to 26.2 , with CV values ranging from 2.58 to $9.77 \%$. Inter-assay variation did not attain statistical significance (ANOVA; $F=0.6064$, $\mathrm{p}=0.62)$.
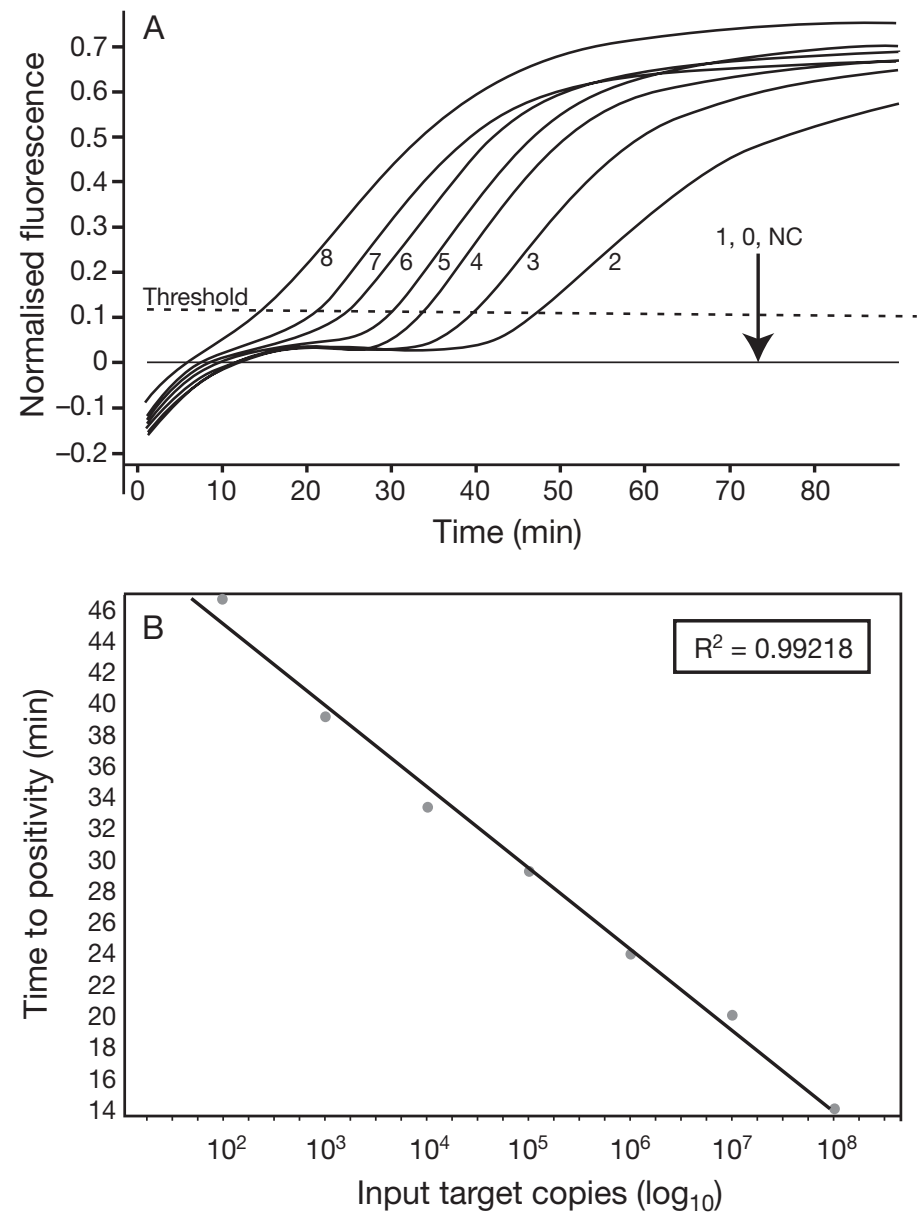

Fig. 2. NASBA of a dilution series of a synthetic transcript corresponding to nucleotides 1-872 of ISAV genome segment 8 . Amplification and detection were as described in 'Materials and methods'. (A) Amplification plot of serial dilutions of target RNA. Input target copies tested were $\left(\log _{10}\right): 8,7,6,5,4,3,2,1,0$. $\mathrm{NC}=$ negative control. (B) Standard curve of serial dilutions of ISAV segment 8 synthetic transcript

\section{DISCUSSION}

We have developed a real-time NASBA assay for the detection of ISAV. The assay was able to detect diverse ISAV isolates from Scotland, Norway, and the Faroe Islands. The NASBA assay also detected a Canadian ISAV strain (data not shown), however this virus was propagated in the SHK-1 cell line prior to use in NASBA testing. We were unable to source clinical samples from Canada for analysis in the present study.

The detection limit of the real-time NASBA assay was between $10^{2}$ and $10^{1}$ target copies based on detection of a synthetic RNA comprising 872 nucleotides of ISAV genome segment 8. In comparison, the detection limit of the RT-PCR procedure was between $10^{4}$ and 
Table 2. Comparison of real-time NASBA and RT-PCR for detection of ISAV in a decimal dilution series of 3 ISAV-positive clinical samples. RT-PCR results: amplification product from a given sample dilution detected (+) or not detected (-) on agarose gel electrophoresis visualised under UV illumination. Tp = time (in min) to positivity; Tp values <90 min are interpreted as positive (see 'Materials and methods'). NT $=$ not tested

\begin{tabular}{|c|c|c|c|c|c|c|c|c|c|c|c|c|c|c|c|c|}
\hline \multirow[t]{2}{*}{ Sample } & \multicolumn{2}{|c|}{ Undiluted } & \multicolumn{2}{|r|}{$10^{-1}$} & \multicolumn{2}{|r|}{$10^{-2}$} & \multicolumn{2}{|r|}{$10^{-3}$} & \multicolumn{2}{|r|}{$10^{-4}$} & \multicolumn{2}{|c|}{$10^{-5}$} & \multicolumn{2}{|c|}{$10^{-6}$} & \multicolumn{2}{|c|}{$10^{-7}$} \\
\hline & $\begin{array}{l}\text { RT- } \\
\text { PCR }\end{array}$ & $\begin{array}{c}\text { NASBA } \\
(\mathrm{Tp})\end{array}$ & $\begin{array}{l}\text { RT- } \\
\text { PCR }\end{array}$ & $\begin{array}{c}\text { NASBA } \\
(\mathrm{Tp})\end{array}$ & $\begin{array}{l}\text { RT- } \\
\text { PCR }\end{array}$ & $\begin{array}{c}\text { NASBA } \\
(\mathrm{Tp})\end{array}$ & $\begin{array}{l}\text { RT- } \\
\text { PCR }\end{array}$ & $\begin{array}{c}\text { NASBA } \\
(\mathrm{Tp})\end{array}$ & $\begin{array}{l}\text { RT- } \\
\text { PCR }\end{array}$ & $\begin{array}{c}\text { NASBA } \\
(\mathrm{Tp})\end{array}$ & $\begin{array}{l}\text { RT- } \\
\text { PCR }\end{array}$ & $\begin{array}{c}\text { NASBA } \\
(\mathrm{Tp})\end{array}$ & $\begin{array}{l}\text { RT- } \\
\text { PCR }\end{array}$ & $\begin{array}{c}\text { NASBA } \\
(\mathrm{Tp})\end{array}$ & $\begin{array}{l}\text { RT- } \\
\text { PCR }\end{array}$ & $\begin{array}{l}\text { NASBA } \\
\text { (Tp) }\end{array}$ \\
\hline 18 & + & NT & + & 26.15 & + & 31.15 & + & 35.15 & + & 35.59 & - & 45.22 & - & 52.69 & NT & $>90$ \\
\hline 19 & + & NT & + & 28.11 & + & 32.22 & + & 38.58 & + & 43.15 & - & 45.46 & - & 49.16 & NT & $>90$ \\
\hline 20 & + & NT & + & 32.29 & + & 36.44 & + & 38.99 & - & 45.42 & - & 48.51 & - & $>90$ & NT & $>90$ \\
\hline
\end{tabular}

Table 3. Intra-assay and inter-assay variation of real-time NASBA for detection of ISAV. Intra-assay variation was estimated by testing 10 replicates of 3 ISAV-positive samples in a single experiment. Inter-assay variation was estimated by testing 10 replicates of an ISAV-positive sample in 4 separate experimental runs. $\mathrm{Tp}=$ time (in $\mathrm{min}$ ) to positivity (see 'Materials and methods' $) . \mathrm{SD}=$ standard deviation. $\mathrm{CV}=$ coefficient of variation

\begin{tabular}{|lccll|}
\hline Sample & Replicates (n) & Mean Tp & SD & CV (\%) \\
\hline Intra-assay & & & & \\
A & 10 & 11.7 & 0.423 & 3.615 \\
B & 10 & 25.7 & 2.51 & 9.77 \\
C & 10 & 41.3 & 3.16 & 8.71 \\
Inter-assay & & & & \\
B-1 & 10 & 25.7 & 2.51 & 9.77 \\
B-2 & 10 & 26.2 & 0.665 & 2.58 \\
B-3 & 10 & 25.3 & 1.74 & 6.877 \\
B-4 & 10 & 25.4 & 1.32 & 5.196 \\
\hline
\end{tabular}

$10^{3}$ copies. When used to detect serial dilutions of clinical samples, the NASBA assay was $100 \times$ more sensitive than conventional RT-PCR. These findings are in agreement with other studies, which have demonstrated NASBA to be of greater sensitivity than RTPCR (Birch et al. 2001, Jean et al. 2001, Wacharapluesadee \& Hemachudha 2001) or real-time RT-PCR assays utilising Taqman chemistry (Lanciotti \& Kerst 2001). The detection limit of the NASBA assay developed in the present study is within the range of $10^{3}$ to $10^{0}$ target copies reported elsewhere (Polstra et al. 2002, Starkey et al. 2004, Ginocchio et al. 2005).

The ISAV-NASBA assay exhibited a broad dynamic range of 6 orders of magnitude, and the $\mathrm{CV}$ of $\mathrm{Tp}$ values ranged from 2.58 to $9.77 \%$. This finding is in agreement with the $\mathrm{CV}$ values reported for NASBA detection of other viruses (Yates et al. 2001, Chantratita et al. 2004). Although in the present study we have used the ISAV-NASBA for qualitative analysis, the dynamic range and reproducibility indicate that the assay could also be used quantitatively to estimate virus load in clinical material.
When used to detect ISAV in a panel of clinical samples, the real-time NASBA yielded results that were in exact agreement with those obtained using a conventional RT-PCR for ISAV detection (Mjaaland et al. 1997). Both assays detected ISAV in 19 of 45 clinical samples. Given the greater sensitivity of the NASBA assay, this finding suggests that the positive samples contained relatively high levels of ISAV. In future studies, it would be interesting to compare the NASBA procedure with RT-PCR for analysis of samples predicted to contain lower levels of ISAV, such as those from persistently infected wild fish.

A real-time RT-PCR procedure for detection of ISAV was described by Munir \& Kibenge (2004). Comparison of this RT-PCR assay with the real-time NASBA procedure developed in the present study is compromised because in the former, the detection limit was not estimated in relation to target copy number. However, both assays were approximately 100× more sensitive than conventional RT-PCR, which suggests that their detection limits may be similar. The real-time RT-PCR assay developed by Munir \& Kibenge (2004) utilised SyBr Green I (SG) for fluorescent detection, rather than a target-specific probe as used in realtime NASBA. The use of SG has been criticised for susceptibility to false positive reactions (Simpson et al. 2000). Furthermore, Monis \& Griglio (2006) detected a single product when using SG in melt curve analysis, but multiple products in agarose gel electrophoresis, with potential implications when using SG for fluorescent detection in routine virus diagnosis. However, the use of SG for fluorescent detection can also be advantageous, since its binding efficiency is not affected by nucleotide sequence variation at probe recognition sites, which could theoretically impair the efficiency of the molecular beacon used in the ISAV NASBA assay.

Since the commencement of the present study, ISAV detection procedures have been developed utilising real-time RT-PCR with MGB probe detection (Plarre et al. 2005), and rolling circle amplification with molecular padlock probe detection (Millard et al. 2006). It 
would be interesting to compare the comparative performance of these molecular detection procedures with the ISAV NASBA assay. In preliminary ring-testing studies, the ISAV NASBA matched the performance of a real-time RT-PCR that used MGB probe detection (authors' unpubl. data); however, further comparative analyses of these ISAV detection procedures are required.

NASBA offers a number of advantages over conventional RT-PCR. The NASBA assay is simple, rapid, and does not require the use of hazardous chemicals such as ethidium bromide for analysis of amplification reactions. In real-time NASBA, amplification and detection are performed in 'closed-tube' format, minimising the potential for false positive results arising from amplicon contamination. Primer annealing in NASBA occurs at lower temperatures than PCR, permitting amplification of targets that do not exactly match primer sequences. Real-time NASBA can also be used to obtain quantitative data, and will be of use in studies of ISAV pathogenesis, diagnostics, and for environmental monitoring. Furthermore, the recently developed miniaturized real-time NASBA procedure utilising nanolitre-scale reaction volumes (Gulliksen et al. 2004) will facilitate high throughput screening for fish viruses such as ISAV.

Although the performance of the real-time ISAVNASBA was encouraging, further characterisation of the assay should be undertaken prior to its routine use for ISAV detection. Firstly, analysis of greater numbers of clinical samples should be performed, including samples from geographic areas not studied in this report such as the United States, Ireland, and Chile. Secondly, the use of archival samples precluded a comparison of the NASBA assay with virus isolation in an ISAV-permissive cell line such as SHK-1. A comparison of the ISAV-NASBA assay with established cell culture methods is recommended prior to its use for routine ISAV detection. Thirdly, no computer algorithms are available to facilitate the design of primers used in NASBA assays. Consequently, the NASBA primers used in the present study were designed empirically. Since the commencement of this study, further ISAV sequences have been added to the Genbank database. This sequence data could be used to design other, potentially more efficient primers capable of detecting a wider range of ISAV strains. Ideally, monitoring of the nucleotide sequence of circulating viruses should be undertaken to ensure that primers remain effective for the routine detection of ISAV.

In summary, we have developed a real-time NASBA assay for detection of ISAV. Real-time detection was performed with a target-specific molecular beacon. The assay was rapid, sensitive and specific, and was capable of detecting strains of ISAV isolated from sev- eral countries. The NASBA assay is less labour intensive than conventional RT-PCR methods for ISAV detection. Real-time NASBA may represent a useful molecular tool for ISAV diagnosis and screening.

Acknowledgements. This study was funded by award QLK2CT-2001-00844 from the European Union Framework 5 programme. We are grateful to Pierre van Aarle of Biomerieux, Boxtel, The Netherlands for assistance in the development of NASBA methodology.

\section{LITERATURE CITED}

Anonymous (2002) Infectious salmon anemia virus. International Committee on Taxonomy of Viruses, 00.046.0.05.001. Available at: www.ncbi.nlm.nih.gov/ ICTVdb/Ictv/index.htm

Birch L, Dawson CE, Cornett JH, Keer, JT (2001) A comparison of nucleic acid amplification techniques for the assessment of bacterial viability. Lett Appl Microbiol 33:296-301

Chantratita W, Pongtanapisit W, Piroj W, Srichunrasmi C, Seesuai S (2004) Development and comparison of the realtime amplification methods, NASBA-beacon, RT-PCTTaqman and RT-PCR hybridization probe assays for the quantitative detection of SARS coronavirus. Southeast Asian J Trop Med Public Health 35:623-629

Cipriano RC, Millar O (eds) (2003) Infectious salmon anaemia: the current state of our knowledge. In: International response to infectious salmon anaemia: prevention, control and eradication. Proceedings of a symposium; September 3-4, 2002, New Orleans, LA. Technical Bulletin 1902: US Department Agriculture, Animal and Plant Inspection Service, US Department of the Interior, US Geological Survey, US Department of Commerce, National Marine Fisheries Service, Washington, DC, p 1-11

Clouthier SC, Rector T, Brown NE, Anderson ED (2002) Genomic organisation of infectious salmon anaemia virus. J Gen Virol 83:421-428

Compton J (1991) Nucleic acid sequence based amplification. Nature 350:91-92

Cunningham CO, Snow M (2000) Genetic analysis of infectious salmon anaemia virus from Scotland. Dis Aquat Org 41:1-8

Dale OB, Kvellestad A, Falk K (2005) Infectious salmon anaemia virus: a disease of the vascular system. Presentation O-146, 12th Conf Eur Assoc Fish Pathologists, Copenhagen

Dannevig BH, Falk K, Namork E (1995) Isolation of the causal virus of infectious salmon anemia virus (ISA) in a long term cell line from salmon head kidney. J Gen Virol 76: 1353-1359

De Baar MP, van der Schoot AM, Goudsmit J, Jacobs F and 5 others (1999) Design and evaluation of a human immunodeficiency virus type 1 RNA assay using nucleic acid sequence based amplification technology able to quantify both group $\mathrm{M}$ and $\mathrm{O}$ viruses by using the long terminal repeat as target. J Clin Microbiol 37:1813-1818

Devold M, Krossoy B, Aspehaug V, Nylund A (2000) Use of RT-PCR for diagnosis of infectious salmon anaemia virus (ISAV) in carrier sea trout Salmo trutta after experimental infection. Dis Aquat Org 40:9-18

Falk K, Dannevig BH (1995) Demonstration of infectious salmon anaemia (ISA) viral antigens in cell cultures and tissue sections. Vet Res 26:499-504 
Ginocchio CC, Zhang F, Malhotra A, Manji R, Foolen H, Overdyk M, Peeters M (2005) Development, technical performance, and clinical evaluation of a NucliSens basic kit application for detection of enterovirus RNA in cerebrospinal fluid. J Clin Microbiol 43:2626-2623

Gregory A (2002) Detection of infectious salmon anaemia virus (ISAV) by in situ hybridisation. Dis Aquat Org 50:105-110

Gulliksen A, Solli L, Karlsen F, Rogne H, Hovig E, Nordstrom T, Sirevag R (2004) Real-time nucleic acid sequence based amplification in nanoliter volumes. Anal Chem 76:9-14

Heim A, Schumann J (2002) Development and evaluation of a nucleic acid sequence based amplification protocol for the detection of enterovirus RNA in cerebrospinal fluid samples. J Virol Methods 103:101-107

Hibbitts S, Rahman A, John R, Westmoreland D, Fox JD (2003) Development and evaluation of NucliSens basic kit NASBA for diagnosis of parainfluenza virus infection with end point and real time detection. J Virol Methods 108: 145-155

Hovland T, Nylund A, Watanabe K, Endresen C (1994) Observation of infectious salmon anaemia virus in Atlantic salmon, Salmo salar L. J Fish Dis 17:291-296

Jean J, Blais B, Darveau A, Fliss I (2001) Detection of hepatitis A virus by the nucleic acid sequence based amplification technique and comparison with reverse transcriptionPCR. Appl Environ Microbiol 67:5593-5600

Keightley MC, Sillikens P, Schippers W, Rinaldo C, St.George K (2005) Real-time NASBA detection of SARS-associated coronavirus and comparison with real-time reverse transcription-PCR. J Med Virol 77:602-608

Kibenge FS, Garate ON, Johnson G, Arriagada R, Kibenge MJ, Wadowska D (2001) Isolation and identification of infectious salmon anaemia virus from Coho salmon in Chile. Dis Aquat Org 45:9-18

Krossoy B, Nilsen F, Falk K, Endresen C, Nylund A (2001) Phylogenetic analysis of infectious salmon anaemia virus isolates from Norway, Canada and Scotland. Dis Aquat Org 44:1-6

Lanciotti RS, Kerst AJ (2001) Nucleic acid sequence based amplification assays for rapid detection of West Nile and St Louis encephalitis viruses. J Clin Microbiol 39: $4506-4513$

Leone GH, van Schijndel H, van Gemen B, Kramer FR, Schoen CD (1998) Molecular beacon probes combined with amplification by NASBA enables homogenous real time detection of RNA. Nucleic Acids Res 26:2150-2155

Millard PJ, Bickerstaff LE, LaPatra SE, Kim SE (2006) Detection of infectious haematopoietic necrosis virus and infectious salmon anaemia virus by molecular padlock amplification. J Fish Dis 29:210-213

Mjaaland S, Hungnes O, Teog A, Dennevig BH, Thorud, K, Rinstadt E (1997) Genomic characterisation of the virus causing infectious salmon anaemia in Atlantic salmon (Salmo salar L.): an orthomyxovirus-like virus in a teleost. J Virol 71:7681-7686

Monis PT, Giglio S (2006) Nucleic acid amplification-based techniques for pathogen detection and identification.

Editorial responsibility: Carey Cunningham,

Aberdeen, UK
Infect Genet Evol 6:2-12

Moore C, Hibbitts S, Owen N, Corden SA, Harrison G, Fox J, Gelder C, Westmoreland D (2004) Development and evaluation of a real-time nucleic acid sequence based amplification assay for rapid detection of influenza A. J Med Virol 74:619-628

Munir K, Kibenge FSB (2004) Detection of infectious salmon anaemia virus by real-time RT-PCR. J Virol Methods 117: $37-47$

Nylund A, Jakobsen P (1995) Sea trout as a carrier of infectious salmon anaemia virus. J Fish Biol 47:174-176

Nylund A, Alexandersen S, Rolland JB, Jakobsen P (1995) Infectious salmon anaemia virus (ISAV) in brown trout. J Aquat Anim Health 7:236-240

Nylund A, Kvenseth AM, Krossoy B, Hodneland K (1997) Replication of the infectious salmon anaemia virus (ISAV) in rainbow trout (Oncorhynchus mykiss). J Fish Dis 20: $275-279$

Nylund A, Devold M, Mullins J, Plarre H (2002) Herring (Clupea harengus): A host for infectious salmon anemia virus (ISAV). Bull Eur Assoc Fish Path 22:311-318

Plarre H, Devold M, Snow M, Nylund A (2005) Prevalence of infectious salmon anaemia virus (ISAV) in wild salmonids in western Norway. Dis Aquat Org 66:71-79

Polstra AM, Goudsmit J, Cornelissen M (2002) Development of real time NASBA assays with molecular beacon detection to quantify mRNA coding for HHV-8 lytic and latent genes. BMC Infect Dis 2:18. Available at: www.biomed central.com/1471-2334/2/18

Rimstad E, Falk K, Mikalsen AB, Teig A (1999) Time course tissue distribution of infectious salmon anaemia virus in experimentally infected Atlantic salmon Salmo salar. Dis Aquat Org 36:107-112

Simpson DA, Feeney S, Boyle C, Stitt AW (2000) Retinal VEGF mRNA measured by $\mathrm{SyBr}$ green I fluorescence: a versatile approach to quantitative PCR. Mol Vis 6:178-183

Starkey WG, Millar RM, Jenkins ME, Ireland JH, Muir KF, Richards RH (2004) Detection of piscine nodaviruses by real-time nucleic acid sequence based amplification (NASBA). Dis Aquat Org 59:93-100

Thorud KE, Djupvik HO (1988) Infectious salmon anaemia in Atlantic salmon (Salmo salar L.). Bull Eur Assoc Fish Path 8:109-111

Wacharapluesadee S, Hemachudha T (2001) Nucleic acid sequence based amplification in the rapid diagnosis of rabies. Lancet 358:892-893

Witt DJ, Kemper M, Stead A, Sillekins P and 6 others (2000) Analytical performance and clinical utility of a nucleic acid sequence-based amplification assay for detection of cytomegalovirus infection. J Clin Microbiol 38:3994-3999

Yates S, Penning M, Goudsmit J, Frantzen I, Weijer B, Strijp D, Gemen R (2001) Quantitative detection of hepatitis B virus DNA by real-time nucleic acid sequence based amplification with molecular beacon detection. J Clin Microbiol 39:3656-3665

Zuker M (2003) Mfold web server for nucleic acid folding and hybridization prediction. Nucleic Acids Res 31:3406-3415

Submitted: January 30, 2006; Accepted: July 20, 2006

Proofs received from author(s): October 3, 2006 